\title{
Effect of electrical cardioversion on myocardial cells in patients in intensive care
}

\author{
G Neumayr, P Schratzberger, G Friedrich, H Gänzer, C J Wiedermann
}

For about 30 years electrical cardioversion has been routine for converting arrhythmias. ${ }^{1}$ Whether the application of shocks in the usual dosage is safe is still controversial as minimal myocardial cell injury cannot be excluded. ${ }^{2}$ If simultaneous muscle damage occurs the measurement of common cardiac markers, especially creatine kinase and its isoenzyme creatine kinase $\mathrm{MB}$, lacks specificity. We therefore also measured the concentration of cardiac troponin $\mathrm{T}$ as this is the most sensitive and specific marker to date.

\section{Patients, methods, and results}

Over the past three years in this unit 69 non-selected patients with atrial fibrillation (aged 21-87, mean 63.7 years) underwent elective countershock using a direct current. Serum samples were taken before and 24 hours after cardioversion. The concentrations of cardiac troponin T, total creatine kinase, and creatine kinase MB were measured by enzyme linked immunosorbent assay (Boehringer, Germany) (reference ranges $<0.1 \mu \mathrm{g} / \mathrm{l}, 10-80 \mathrm{U} / \mathrm{l}$, and $<12 \mathrm{U} / \mathrm{l},<6 \%$ respectively). A total of 153 shocks was delivered, amounting to an average cumulative energy of $286 \mathrm{~J}$ per patient. Cardioversion was started with $50 \mathrm{~J}$ of stored energy, and subsequent shocks comprised 100, 200, 300, and $360 \mathrm{~J}$. The procedure was terminated after restoration of sinus rhythm or after two attempts of 360 $\mathrm{J}$ each.

Four patients received the highest amount of cumulative energy $(1370 \mathrm{~J})$. Sixty seven patients converted to sinus rhythm, and no major complications occurred. At follow up 24 hours later 60 patients had restored sinus rhythm. All measurements of cardiac troponin $\mathrm{T}$ activity before and after cardioversion were below $0.1 \mu \mathrm{g} / \mathrm{l}$. The baseline concentrations and peak activities of creatine kinase and creatine kinase MB were within the normal range except in three cases. In one patient the peak activity of total creatine kinase increased from 13 to $103 \mathrm{U} / 1$ but that of creatine kinase MB was normal. In the other two patients the peak activity of creatine kinase was increased from 32 to $363 \mathrm{U} / 1$ and from 18 to $512 \mathrm{U} / 1$ and that of creatine kinase $\mathrm{MB}$ by $33 \mathrm{U} / 1$ and by $42 \mathrm{U} / 1$ respectively.

\section{Comment}

Experiments in animals have shown that necrosis of myocardial cells occurs after repeated countershocks using direct currents of high energy. ${ }^{3}$ Evidence that electrical cardioversion may result in myocardial damage in humans is based on the increased concentrations of various cardiac enzymes measured after cardioversion. ${ }^{4}$
To overcome the problem of insufficient specifity of cardiac enzymes we measured the activity of cardiac troponin T. Cardiac troponin $\mathrm{T}$ is not detectable in the serum of healthy people and can be differentiated from its isoforms in skeletal muscle by immunological techniques; its cross reactivity to mixed skeletal muscle is $1-2 \%$, and its specificity is $95 \%$ in the presence of skeletal damage. ${ }^{5}$ Currently, cardiac troponin $\mathrm{T}$ is the best marker for detecting minimal myocardial damage, especially when skeletal muscles are also injured.

In our non-selected patient population countershock using direct current was highly effective and without major complications. As we did not find any increase in plasma activity of cardiac troponin $\mathrm{T}$ we conclude that myocardial cell injury by electrical cardioversion is unlikely when applying cumulative energies of up to $1370 \mathrm{~J}$. As two patients had raised concentrations of total creatine kinase and creatine kinase MB but not of cardiac troponin T, we conclude that these enzymes originated from injured skeletal muscle. We therefore suggest that the increased concentrations of creatine kinase and creatine kinase MB reported previously in cases of myocardial damage could also have originated from injured skeletal muscle.

Contributors: GN is guarantor for the paper. PS, GF, HG, and CJW contributed to the study design, analysis of the data, and revision of the paper.

Funding: None.

Conflict of interest: None.

1 Lown B, Amarasingham R, Neuman J. New method of termination of cardiac arrhythmias. JAMA 1962;182:548-55.

2 Metcalfe MJ, Smith F, Jennings K, Paterson N. Does cardioversion of atrial fibrillation result in myocardial damage? BMJ 1988;296:1364.

3 Doherty PW, McLaughlin PR, Billingham M, Kernoff R, Goris ML, Harrison DC, et al. Cardiac damage produced by direct current countershock applied to the heart. Am J Cardiol 1978;43:225-8.

4 Eshani A, Gordon AK, Sobel BE. Effects of electrical countershock on serum creatine phosphokinase (CPK) isoenzyme activity. Am J Cardiol 1976;37:12-8.

5 Katus HA, Remppis A, Neumann FJ, Scheffold T, Diederich KW, Vinar G, et al. Diagnostic efficiency of troponin T measurements in acute myocardial infarction. Circulation 1991;83:902-12.

(Accepted 27 November 1997)

\section{Endpiece}

Who's out there?

Communication today has four characteristics; it is global, permanent, immediate, and immaterial. Previously only God had these qualities.

Ignatio Ramonet (of Le Monde Diplomatique) quoted in UNESCO Sources, April 1997
Medical and

Intensive Care Unit Department of Internal Medicine, University of Innsbruck, A-6020 Innsbruck, Austria G Neumayr, doctor

P Schratzberger,

doctor

G Friedrich,

doctor

H Gänzer,

doctor

C J Wiedermann,

doctor

Correspondence to: Dr Neumayr

BMJ 1998;316:1207 